DOI https://doi.org/10.18551/rjoas.2021-02.04

\title{
IMPROVEMENT QUALITY OF BRACKISH WATERS THROUGH SEAWEED SCENARIO MODEL OF GRACILARIA SP. AS BIOFILTER AGENT
}

\author{
Mulatsih Sri ${ }^{\star}$, Suyono, Sutaman, Hartanti Ninik Umi, Narto \\ Faculty of Fisheries and Marine Sciences, University of Pancasakti, Tegal City, Indonesia \\ *E-mail: srimulatsih138@gmail.com
}

\begin{abstract}
Development of aquaculture, especially shrimp brackish in coastal areas will greatly affect the quality of the coastal environment. Mistakes in the management of shrimp culture will lead to a decrease in environmental quality that will threaten the sustainability of coastal resources and ultimately endanger the continuity of cultivation. Decreasing the feasibility of aquatic quality as a result of disposal of cultivated waste operations can affect the life of shrimp that is cultivated can even lead to crop failure and declining productivity function of cultivated land. This research was conducted in coastal area of Brebes Sub-district, Brebes Regency. The method used in the research is direct survey in the field to obtain primary data. The results of this study showed that the presence of seaweed biofilter showed an increase in water conditions and ponds located in coastal areas of Brebes. Seaweed biofilter gives the result of absorption of Nitrogen $(\mathrm{N})$ content of $0.08 \%$, phosphorus content of $0.01 \%$ and organic $\mathrm{C}$ content absorbed in seaweed by $0.07 \%$. Improving the quality of pond waters with the existence of seaweed cultivation makes a difference the organic matter content of elements of $\mathrm{N}$ and $\mathrm{P}$ compared with those not planted with seaweed. It can be seen from organic matter content, $\mathrm{N}$ and $\mathrm{P}$ is $112,72 \%$ for organic material, $0,34 \%$ for $\mathrm{N}$ and $\mathrm{P}$ equal to $0,02 \%$ for brackhishs planted with seaweed, while in brackhish not planted with seaweed material organic content of $106.20 \%, 0.32 \%$ for Nitrogen and $0.01 \%$ for P. During the study of water quality included in the category appropriate for aquaculture. Simulation results and model scenarios with increasing biofilter coefficients show significant rates of cultivation waste reduction accompanied by an increase in farmer's income.
\end{abstract}

\section{KEY WORDS}

Model, water quality, biofilter, pattern of brackish water development.

Decreasing the feasibility of waters quality as a result of disposal of cultivated waste operations can affect the life of shrimp that is cultivated may even causing harvest failure and declining productivity function of cultivated land. Integrated cultivation system between fish and seaweed is expected to improve the feasibility of land for coastal cultivation, as it can reduce the risk of damage to waters quality and nutrients that loose into the environment.

The purpose of this study is to determine the effectiveness and role of seaweed biofilter (Gracilaria sp) in the absorption of waste (N, P) of aquaculture brackhish. The research was carried out in aquaculture of Muarareja Village, Sub district West Tegal, City and Randusanga Wetan Village, Sub district East Brebes, Brebes District in March-July 2015.

\section{METHODS OF RESEARCH}

The data used in this study are primary data was obtained by observative and secondary data. The research data consisted of the growth of seaweed and tiger shrimp, parameter physics-chemical water culture media, and the rate of biodegradation of brackhish waste (N, P and C). Research data processing starded by basic assumption test in the form of Liliefors normality test, Bartlett homogeneity test and Tukey additive test. The difference of treatment result is known by variance analysis to the extent of the difference between treatment outcomes known through the smallest real difference test.

Optimization model is done by using the system approach (dynamic system) in determining the waste load, the carrying capacity and optimization of the allocation of 
fishery aquaculture resources. The dynamic model structure to be constructed from seaweed brackhish model started from input, process, output and feedback. Dynamic models work based on dynamic time changes.

The dynamic system model in this study is used to determine the optimal land utilization allocation for sustainable brackhish development. The model to be built is arranged based on several sub models that affect the development of coastal cultivation. The sub models include: shrimp biomass sub model, sub model of seaweed biomass, sub model of aquaculture (without and with the role of seaweed biofilter), sub model of absorption rate of waste brackhish by seaweed gracilaria sp. as well as sub models of environmental carrying capacity.

Data analysis method was done by dynamic system approach using powersim studio 2005 Enterprise software aid. The operational phase was done by referring to Yusuf (2016) in Sutaman (2017) that is (1) make causal loop diagram which is a reciprocal relationship, (2) Creating a flow diagram representing the reciprocal relationship of existing structures in the form of stock (level), flow, auxiliary, constant and information link, (3) creating a mathematical equation by defining the variables that will be used in mathematical units, (4) Conducting simulations in the period 2015 to 2035. (5) Conduct a validation model that includes the validation of the structure and performance validation. Structural validation is done through a consistency check model with descriptive knowledge of the systems involved in the modeling process. Performance validation is performed using the recommended statistical methods to see conformance to actual performance (factual) using MAPE (Mean Absolute Percentage Error) test.

$$
\text { MAPE }=\frac{1}{n} \sum \frac{X_{m}-X_{d}}{X_{d}} x 100 \%
$$

Where: $\mathrm{Xm}=$ Data of simulation result; $\mathrm{Xd}=$ Actual data; $\mathrm{n}=$ Number of data.

The MAPE value is very accurate describing the real condition if the MAPE value is $<5 \%$. MAPE values ranging from $5 \%$ to $10 \%$ included in the category are sufficiently accurate to describe the real condition and the MAPE value> $10 \%$ then fall into the inappropriate category in describing the real condition (Morecroft, 2007)

\section{RESULTS AND DISCUSSION}

The growth of Gracilaria sp during the study presented in Table 1.

Table 1 - Growth of Biomass Grass (Gram) Seaweed (Gracilaria verrucosa) with Solid Different Stocks

\begin{tabular}{|c|c|c|c|c|c|c|c|}
\hline \multirow{2}{*}{ Treatments } & \multirow{2}{*}{ Repetitions } & \multirow{2}{*}{ Wo } & \multicolumn{5}{|c|}{ Wt, Sampling / Week } \\
\hline & & & $I-I I$ & III - IV & $\mathrm{V}-\mathrm{VI}$ & VII-VIII & $\mathrm{IX}-\mathrm{X}$ \\
\hline \multirow{3}{*}{$\mathrm{A}, 0,06 \mathrm{gram} / \mathrm{m}^{2}$} & 1 & 60 & 70.15 & 84.37 & 116.20 & 133.40 & 149.70 \\
\hline & 2 & 60 & 68.70 & 85.20 & 114.73 & 129.35 & 144.92 \\
\hline & 3 & 60 & 67.95 & 83.76 & 112.85 & 128.87 & 134.42 \\
\hline Different, Average & $+83,01$ & 60 & 68.93 & 84.44 & 114.59 & 130.54 & 143.01 \\
\hline \multirow{3}{*}{$\mathrm{B}, 0,12 \mathrm{gram} / \mathrm{m}^{2}$} & 1 & 120 & 128.93 & 142.30 & 159.06 & 180.27 & 194.73 \\
\hline & 2 & 120 & 126.38 & 140.47 & 156.32 & 175.99 & 184.50 \\
\hline & 3 & 120 & 127.50 & 146.58 & 164.20 & 184.72 & 217.50 \\
\hline Different, Average & $+78,91$ & 120 & 127.60 & 143.12 & 159.86 & 180.33 & 198.91 \\
\hline \multirow{3}{*}{$\mathrm{C}, 0,18 \mathrm{gram} / \mathrm{m}^{2}$} & 1 & 180 & 197.30 & 220.10 & 248.71 & 286.02 & 300.10 \\
\hline & 2 & 180 & 190.45 & 217.68 & 234.45 & 252.17 & 271.40 \\
\hline & 3 & 180 & 199.15 & 223.26 & 252.28 & 290.13 & 320.15 \\
\hline Different, Average & $+117,22$ & 180 & 195.63 & 220.35 & 245.15 & 276.11 & 297.22 \\
\hline \multirow{3}{*}{$\mathrm{D}, 0,24 \mathrm{gram} / \mathrm{m}^{2}$} & 1 & 240 & 249.60 & 262.08 & 270.86 & 284.40 & 296.20 \\
\hline & 2 & 240 & 248.92 & 261.37 & 274.43 & 288.16 & 304.75 \\
\hline & 3 & 240 & 251.26 & 265.78 & 279.07 & 293.02 & 337.50 \\
\hline Different, Average & $+72,82$ & 240 & 249.93 & 262.42 & 274.79 & 288.53 & 312.82 \\
\hline \multirow{3}{*}{$\mathrm{E}, 0,30 \mathrm{gram} / \mathrm{m}^{2}$} & 1 & 300 & 309.00 & 317.69 & 325.48 & 334.58 & 342.97 \\
\hline & 2 & 300 & 313.20 & 318.25 & 328.14 & 340.12 & 338.40 \\
\hline & 3 & 300 & 311.26 & 323.71 & 334.67 & 342.80 & 357.80 \\
\hline Different, Average & $+46,39$ & 300 & 311.15 & 319.88 & 329.43 & 339.17 & 346.39 \\
\hline
\end{tabular}


Gracilaria verrucosa biomass weight growth data are normal, homogeneous and additive and differ significantly between different padatebar. The result of BNT test of $\mathrm{G}$. verrucosa biomass weight growth is presented in Table 2.

Table 2 - BNT Test Results Growth of Absolute Weight Gracilaria sp.

\begin{tabular}{|c|c|c|c|c|c|}
\hline \multirow{2}{*}{ Density $\left(\mathrm{gram} / \mathrm{m}^{2}\right)$} & \multirow{2}{*}{ Average } & \multicolumn{4}{|c|}{ Difference with density $\left(\mathrm{gram} / \mathrm{m}^{2}\right)$} \\
\cline { 3 - 6 } & & 0,18 & 0,06 & 0,12 & 0,24 \\
\hline $\mathrm{C}: 0,18$ & 117.22 & & & & \\
\hline $\mathrm{A}: 0,06$ & 83.01 & $34.21^{*}$ & & & \\
\hline $\mathrm{B}: 0,12$ & 78.91 & 38.31 & 4.10 & & \\
\hline $\mathrm{D}: 0,24$ & 72.82 & 44.40 & 10.19 & 6.09 & \\
\hline $\mathrm{E}: 0,30$ & 46.39 & 70.83 & 36.62 & $32.52^{*}$ & 26.43 \\
\hline
\end{tabular}

$*$ significantly different $(P<0,05)$;

${ }^{* *}=$ very significantly different $(P<0,01)$.

G. verrucosa with density $0.18 \mathrm{~g} / \mathrm{m} 2$ (treatment C) has the best biomass growth than other treatments.

Increasing of individual weights of tiger shrimp during the study presented in Table 3.

Table 3 - Growth individual weight shrimp windu during the study

\begin{tabular}{|c|c|c|c|c|c|c|c|}
\hline \multirow{2}{*}{ Treatments } & \multirow{2}{*}{ Repetitions } & \multirow{2}{*}{ Wo } & \multicolumn{5}{|c|}{ Wt, Sampling / Week (gram) } \\
\hline & & & I-II & III-IV & $\mathrm{V}-\mathrm{VI}$ & VII-VIII & $\mathrm{IX}-\mathrm{X}$ \\
\hline \multirow{3}{*}{$0,00 \mathrm{gram} / \mathrm{m}^{2}$} & 1 & 2.55 & 6.41 & 11.16 & 16.39 & 16.85 & 21.95 \\
\hline & 2 & 2.86 & 6.57 & 10.87 & 17.02 & 20.37 & 24.40 \\
\hline & 3 & 2.99 & 6.34 & 10.96 & 14.81 & 18.94 & 23.36 \\
\hline Different, Average & $+20,44$ & 2.80 & 6.44 & 11.00 & 16.07 & 18.72 & 23.24 \\
\hline \multirow{3}{*}{$0,06 \mathrm{gram} / \mathrm{m}^{2}$} & 1 & 2.12 & 5.66 & 10.51 & 13.76 & 16.58 & 21.45 \\
\hline & 2 & 2.61 & 6.00 & 10.95 & 17.24 & 19.63 & 25.57 \\
\hline & 3 & 2.72 & 6.94 & 11.61 & 17.00 & 22.43 & 26.72 \\
\hline Different, Average & $+22,85$ & 2.38 & 6.20 & 11.02 & 16.00 & 19.55 & 25.23 \\
\hline \multirow{3}{*}{$0,12 \mathrm{gram} / \mathrm{m}^{2}$} & 1 & 2.11 & 5.89 & 10.60 & 14.69 & 19.43 & 24.95 \\
\hline & 2 & 2.65 & 6.88 & 11.63 & 17.96 & 20.43 & 26.94 \\
\hline & 3 & 2.88 & 7.52 & 12.11 & 18.85 & 24.52 & 31.10 \\
\hline Different, Average & $+25,11$ & 2.55 & 6.76 & 11.45 & 17.17 & 21.46 & 27.66 \\
\hline \multirow{3}{*}{$0,18 \mathrm{gram} / \mathrm{m}^{2}$} & 1 & 2.09 & 6.31 & 11.42 & 18.30 & 23.04 & 28.96 \\
\hline & 2 & 2.67 & 7.98 & 12.85 & 18.77 & 23.67 & 30.26 \\
\hline & 3 & 2.83 & 8.31 & 12.94 & 18.87 & 21.48 & 27.35 \\
\hline Different, Average & $+26,33$ & 2.53 & 7.53 & 12.40 & 18.65 & 22.73 & 28.86 \\
\hline \multirow{3}{*}{$0,24 \mathrm{gram} / \mathrm{m}^{2}$} & 1 & 2.60 & 7.35 & 12.14 & 18.56 & 20.84 & 26.96 \\
\hline & 2 & 2.89 & 8.44 & 12.79 & 18.41 & 23.56 & 31.89 \\
\hline & 3 & 2.95 & 8.71 & 13.25 & 19.33 & 26.58 & 31.17 \\
\hline Different, Average & $+25,86$ & 2.81 & 8.17 & 12.73 & 18.77 & 23.66 & 28.67 \\
\hline \multirow{3}{*}{0,30 gram $/ \mathrm{m}^{2}$} & 1 & 2.40 & 6.61 & 11.32 & 16.94 & 22.25 & 27.58 \\
\hline & 2 & 2.76 & 7.82 & 12.00 & 17.61 & 23.87 & 31.06 \\
\hline & 3 & 2.86 & 7.79 & 11.87 & 17.79 & 20.87 & 27.30 \\
\hline Different, Average & $+25,98$ & 2.67 & 7.41 & 12.73 & 17.45 & 22.33 & 28.65 \\
\hline
\end{tabular}

The growth data of individual weights of tiger shrimp are normal, homogeneous and additive and have significant differences between treatments. BNT test results presented in Table 4.

Table 4 - BNT test result of individual weights of tiger shrimp

\begin{tabular}{|c|c|c|c|c|c|c|}
\hline \multirow{2}{*}{ Treatments } & \multirow{2}{*}{ Average } & \multicolumn{5}{|c|}{ Difference with density $\left(\mathrm{gram} / \mathrm{m}^{2}\right)$} \\
\hline & & 0,18 & 0,24 & 0,12 & 0,30 & 0,06 \\
\hline 0,18 & 26,33 & & & & & \\
\hline 0,30 & 25,98 & & & & & \\
\hline 0,24 & 25,86 & 3.34 & 3.34 & & & \\
\hline 0,12 & 25,11 & $4.97^{*}$ & 3.34 & & & \\
\hline 0,06 & 22,85 & $6.67^{*}$ & $6.67^{*}$ & $6.67^{*}$ & 3.33 & \\
\hline 0,00 & 20,44 & $13.34^{*}$ & $13.34^{*}$ & $10.00^{*}$ & $10.00^{*}$ & $6.67^{*}$ \\
\hline
\end{tabular}

${ }^{*}=$ significantly different $(P<0,05)$. 
Density of Gracilaria sp. 0.18 gram $/ \mathrm{m} 2$ gives the best contribution to the growth of individual weights of tiger shrimp.

The data of tiger shrimp survival were normal, homogeneous, additive and significantly different between treatments. BNT test results on the survival rate of tiger shrimp presented in Table 5.

Table 5 - BNT Test Result on Tiger Shrimp Survival Rate

\begin{tabular}{|c|c|c|c|c|c|c|}
\hline \multirow{2}{*}{ Density of Gracilaria sp. (gram $/ \mathrm{m}^{2}$ ) } & \multirow{2}{*}{ Average (\%) } & \multicolumn{5}{|c|}{ Difference with density... $\left(\mathrm{gram} / \mathrm{m}^{2}\right)$} \\
\hline & & 0,18 & 0,24 & 0,12 & 0,30 & 0,06 \\
\hline 0,18 & 76.67 & & & & & \\
\hline 0,24 & 76.67 & & & & & \\
\hline 0,12 & 73.33 & 3.34 & 3.34 & & & \\
\hline 0,30 & 73.33 & 3.34 & 3.34 & & & \\
\hline 0,06 & 70.00 & 6.67 & 6.67 & 6.67 & 3.33 & \\
\hline 0,00 & 63.33 & 13.34 & 13.34 & 10.00 & 10.00 & 6.67 \\
\hline
\end{tabular}

${ }^{*}=$ significantly different $(P<0,05)$.

The survival rate of shrimp on density Gracilaria sp. 0.18 gram / $\mathrm{m} 2$ is relatively the same as 0.24 gram / $\mathrm{m} 2$ density and better than other treatments.

The data of feed conversion ratio of shrimp is normal, homogeneous, but not additive and not significantly different between the spreading density treatments of Gracilaria sp.

Changes of physical-chemical water parameter in culture medium, Gracilaria sp. weight increasing and Tiger Shrimp and their survival are presented in Table 6.

Table 6 - Changes in physical-chemical water parameters, weight gain Gracilaria sp. and tiger shrimp and its survival in various densities of Gracilaria sp.

\begin{tabular}{|c|c|c|c|c|c|c|c|c|}
\hline \multirow{2}{*}{ No } & \multirow{2}{*}{ Aspect } & \multirow{2}{*}{ Parameters } & \multicolumn{6}{|c|}{ Density of Gracilaria sp. (gram $/ \mathrm{m}^{2}$ ) } \\
\hline & & & 0,00 & 0,06 & 0,12 & 0,18 & 0,24 & 0,30 \\
\hline \multirow{6}{*}{1} & \multirow{6}{*}{ Water quality that be limiting factors } & $\mathrm{pH}$ (average) & 7,52 & 7,65 & 7,69 & 7,70 & 7,73 & 7,73 \\
\hline & & DO (ppm) & $+0,16$ & $+0,37$ & $+0,37$ & $+0,74$ & $+0,74$ & $+0,74$ \\
\hline & & Ammonia (ppm) & $-0,06$ & $-0,09$ & $-0,08$ & $-0,15$ & $-0,16$ & $-0,17$ \\
\hline & & Phosphate (ppm) & $-0,01$ & $-0,03$ & $-0,02$ & $-0,04$ & $-0,03$ & $-0,03$ \\
\hline & & Nitrite (ppm) & $-0,28$ & $-0,27$ & $-0,27$ & $-0,28$ & $-0,28$ & $-0,29$ \\
\hline & & Nitrate (ppm) & $-0,28$ & $-0,30$ & $-0,31$ & $-0,31$ & $-0,31$ & $-0,31$ \\
\hline 2 & Growth of Gracilaria sp & Increase in biomass (gram) & -- & $+83,01$ & $+78,91$ & $+117,22$ & $+72,82$ & $+72,82$ \\
\hline 3 & Growth of the Tiger Shrimp & Increase in biomass (gram) & $+20,44$ & $+22,85$ & $+25,11$ & $+26,33$ & $+25,86$ & $+25,98$ \\
\hline 4 & Survival of the Tiger Shrimp & $\%$ of Average & 63,33 & 70,00 & 73,33 & 76,67 & 76,67 & 73,33 \\
\hline
\end{tabular}

At the start of the study, the nitrogen $(\mathrm{N})$ content of $1.90 \%$ was absorbed in seaweed at the base and $1.72 \%$ were already absorbed in seaweed at the tip before the study. At the end of the study, the detected nitrogen $(\mathrm{N})$ content of $2.41 \%$ was absorbed in seaweed at the base and by $2.25 \%$ absorbed at the end of the seaweed. The illustration is presented in Figure 1.

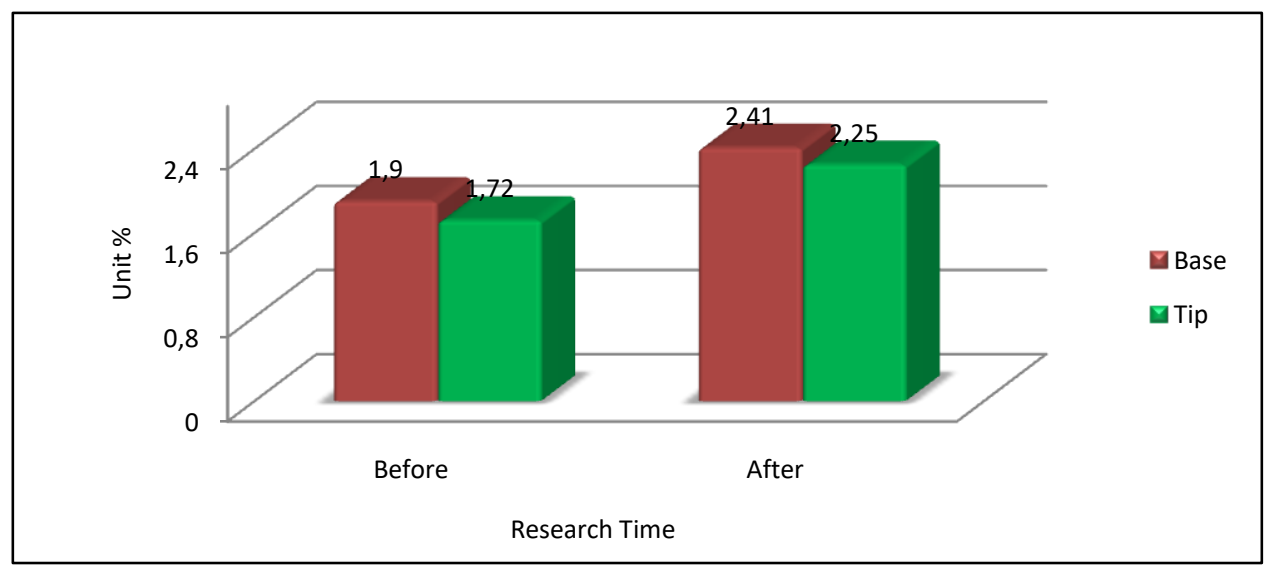

Figure 1 - Content of nitrogen elements absorbed in seaweed 
Phosphorus (P) content that has been absorbed in seaweed the base of $0.15 \%$ and at the tip $0.10 \%$ at the beginning of the study. After the study of phosphorus $(\mathrm{P})$ content was detected $0.13 \%$ absorbed in seaweed at the base and $0.14 \%$ at the tip as illustrated in Figure 2.

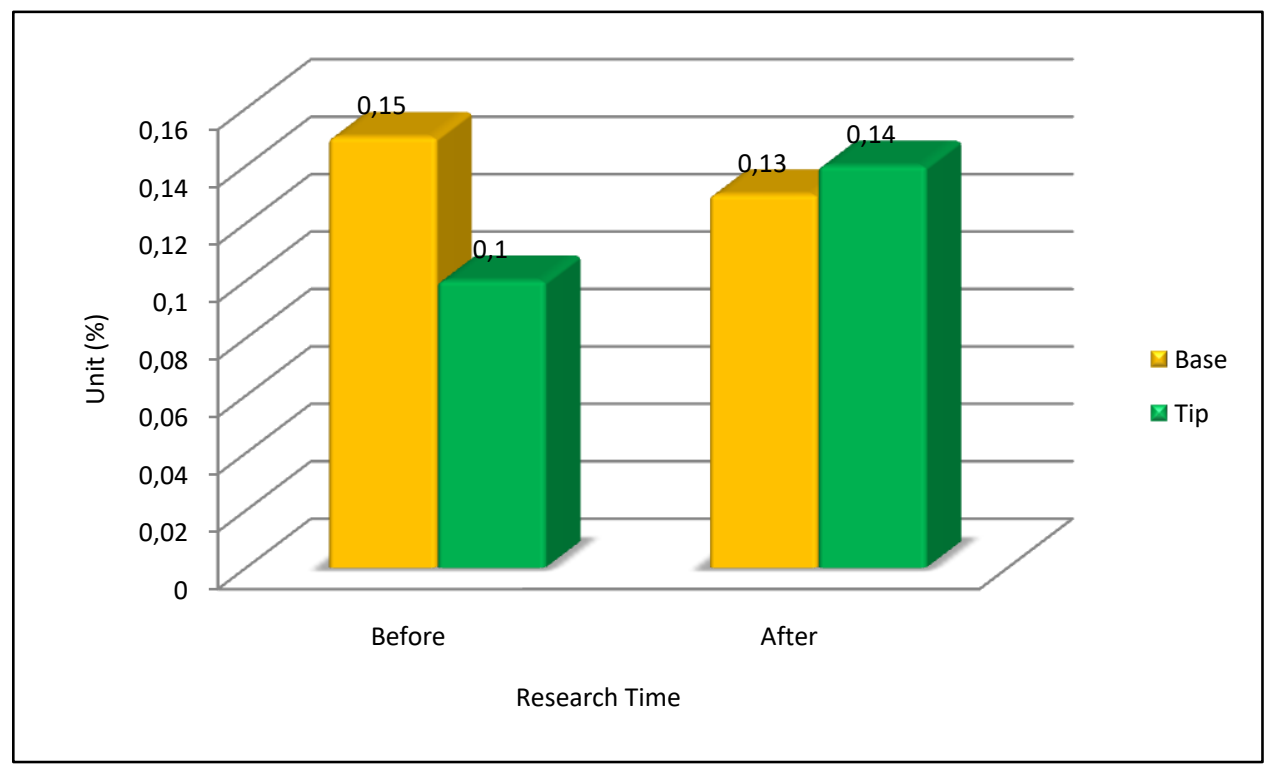

Figure 2 - Content of phosphorus elements absorbed in seaweed

The organic C content absorbed in seaweed at the base of $30.50 \%$ and at the end of $30.32 \%$ before the study. After research of organic content of C was detected $30,71 \%$ absorbed at base of seaweed and $29,93 \%$ absorbed at the tip as shown in Figure 3.

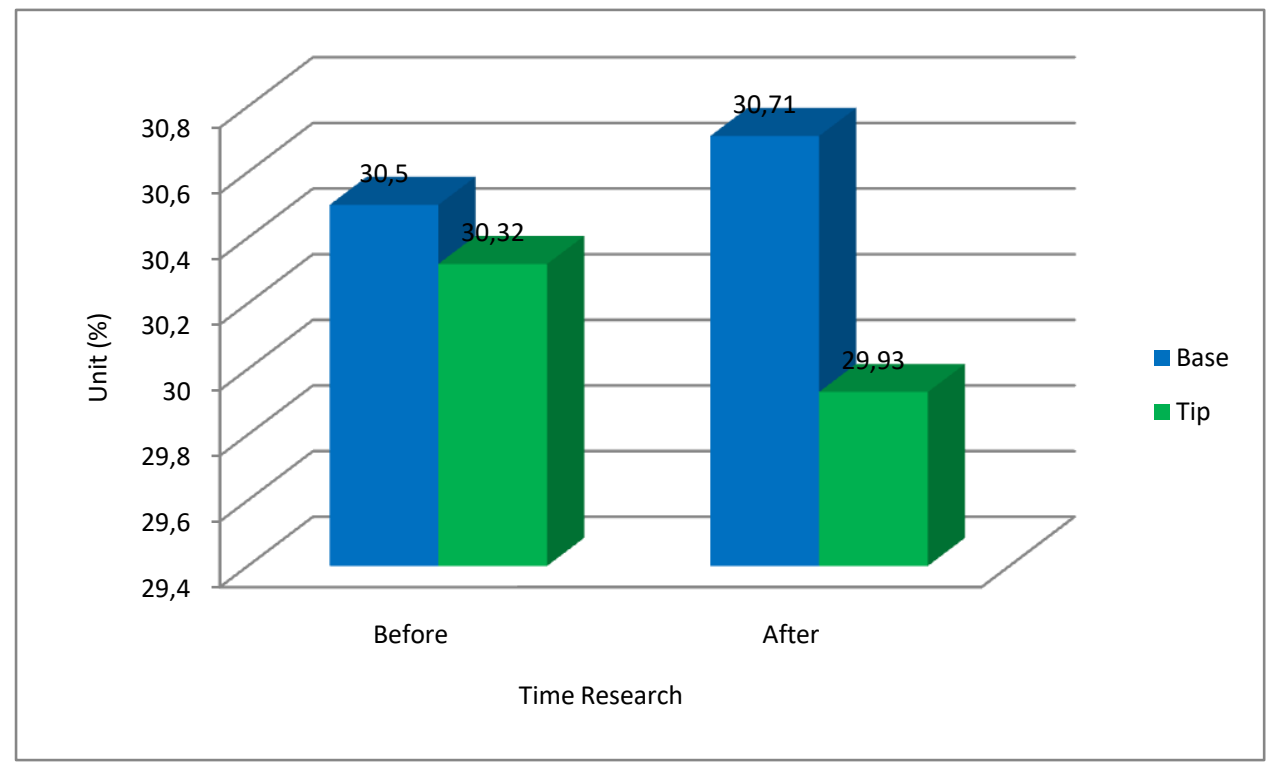

Figure 3 - Content of Organic carbon elements absorbed in seaweed

The organic C content absorbed in seaweed at the base of $30.50 \%$ and at the end of $30.32 \%$ before the study. After research of organic content of C was detected $30,71 \%$ absorbed at base of seaweed and $29,93 \%$ absorbed at the tip as shown in Figure 3.

The causal loop diagram and the dynamic model of shrimp polyculture cultivation with the Gracylaria sp biofilter are presented in Figures 4 and 5. 


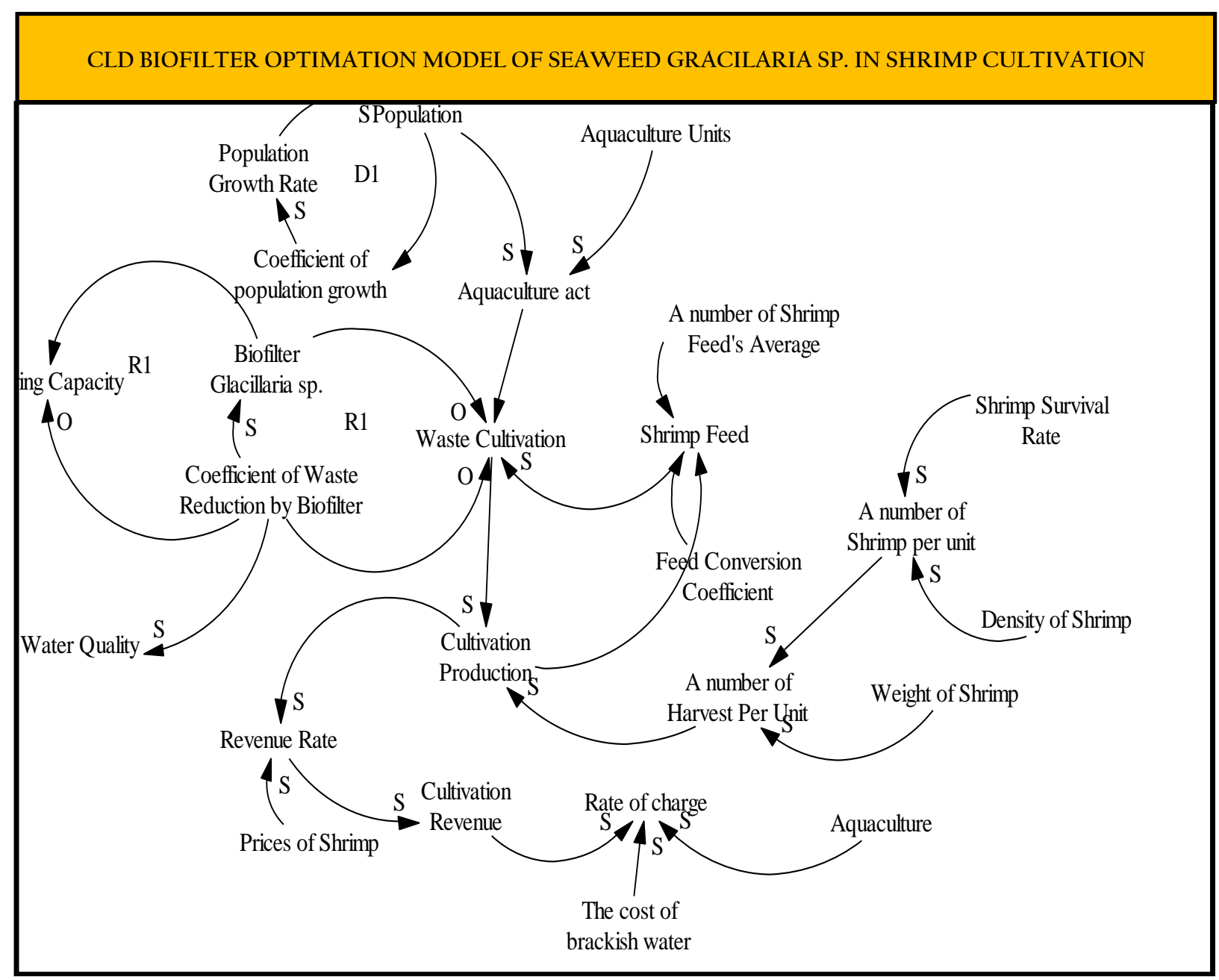

Figure 4 - The causal loop effect of seaweed biofilter to improve water quality of culture media

The validity of the aquaculture model with the biofilter system is done by comparing factual data of the cultivation unit at the study site compared with the simulated model obtained. Database used in 2010. Validated data based on 2010 to 2015.

Table 7 - The data validation of aquaculture culture model

\begin{tabular}{cccc}
\hline Years & $(\mathrm{St})$ & $(\mathrm{At})$ & MAPE \\
\cline { 2 - 3 } & Simulation & Actual & 0 \\
2010 & 20 & 20 & 4,76 \\
2011 & 22 & 21 & 4,76 \\
2013 & 22 & 21 & 9,1 \\
2014 & 24 & 22 & 25 \\
2015 & 25 & 20 & 6,66 \\
\end{tabular}

The result of model validity test obtained MAPE value of $8.38 \%$, the value is still relatively high that is more than $5 \%$, but still below $10 \%$. Morecroft $(2007)$ states that the MAPE value of $5-10 \%$ is still categorized as appropriate to describe the real condition.

Model simulations are performed within 2015-2045. The simulations include cultivation waste prior to being given the role of biofilter, the role of biofilter in reducing biofilter waste, environmental carrying capacity and community income with the role of seaweed biofilter. The existence of a model simulation is intended to provide a temporal picture with the addition and subtraction of the model. 


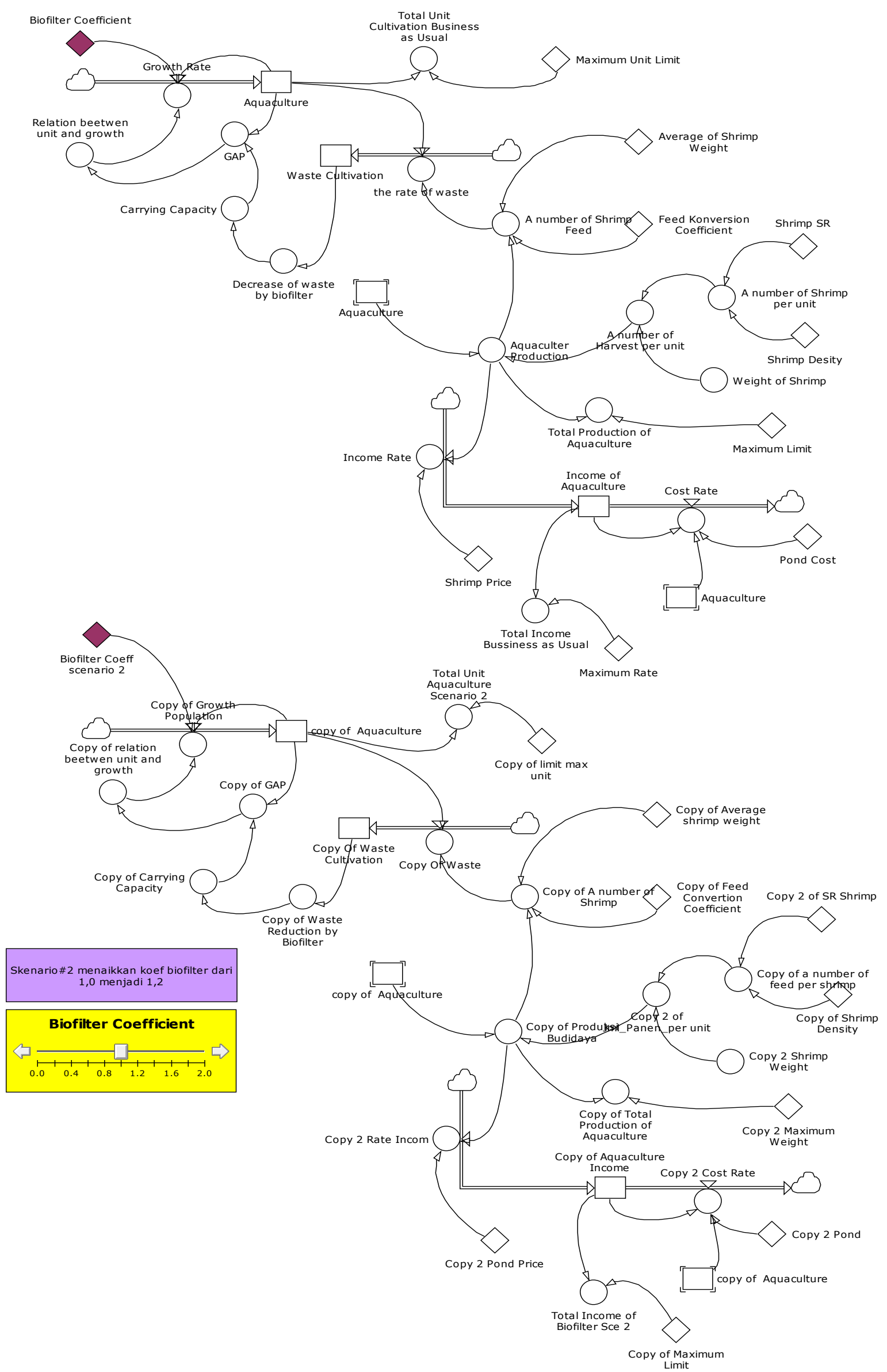

Figure 5 - Dynamic model of shrimp polyculture cultivation with biofilter Gracilaria sp. 
The dynamic model results of biofilter role in sustainable brackish water development are simulated as follows:

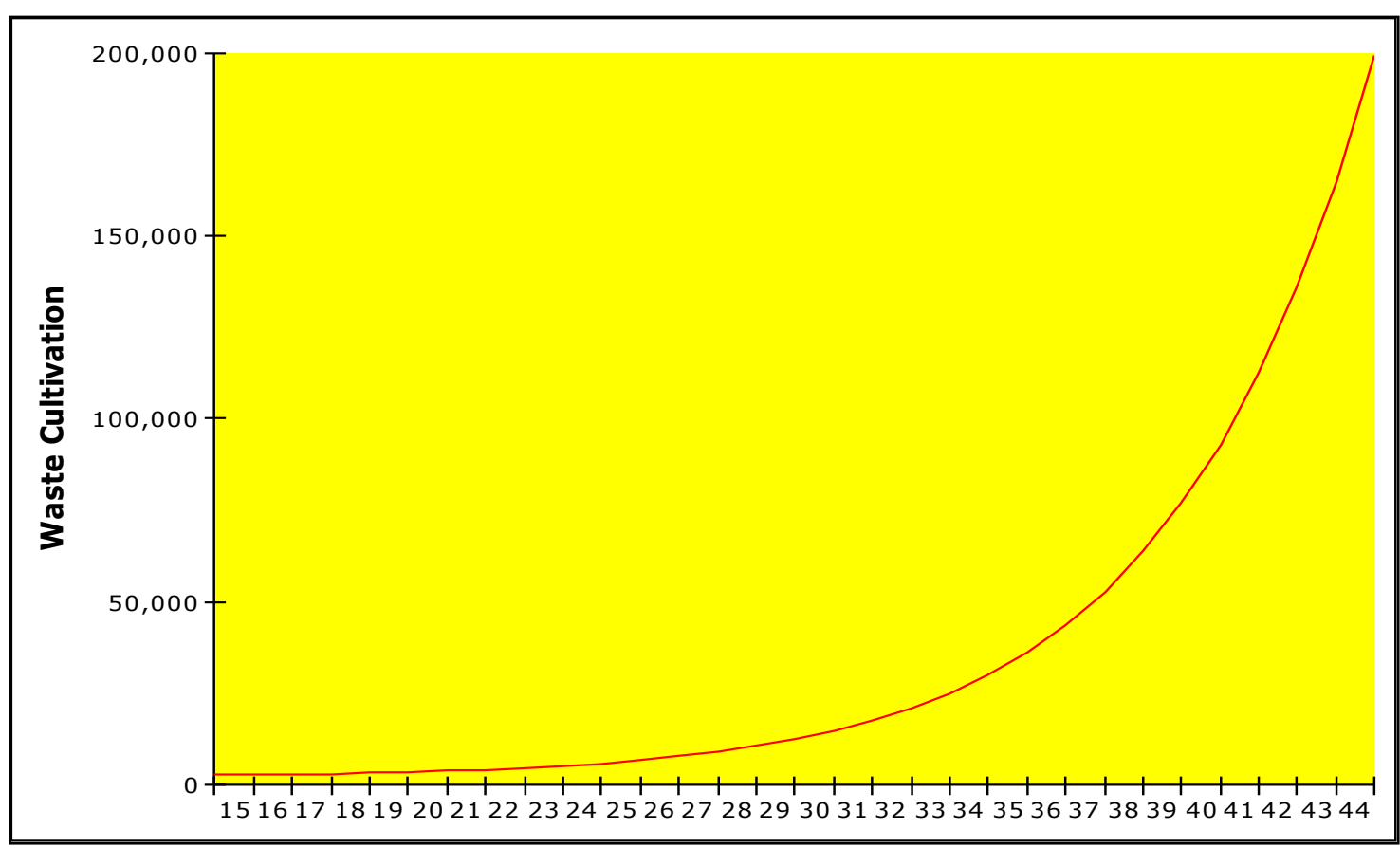

Figure 6 - Graph of cultivation waste simulation $(\mathrm{kg} /$ year)

The result of simulation of sub model of cultivation waste before existence of biofilter role shows growth pattern of exponential growth, or experiencing increase of load with time. Increase in waste based on simulation results in 2026 increased $0.78 \%$ per year, the number continues to increase with the year.

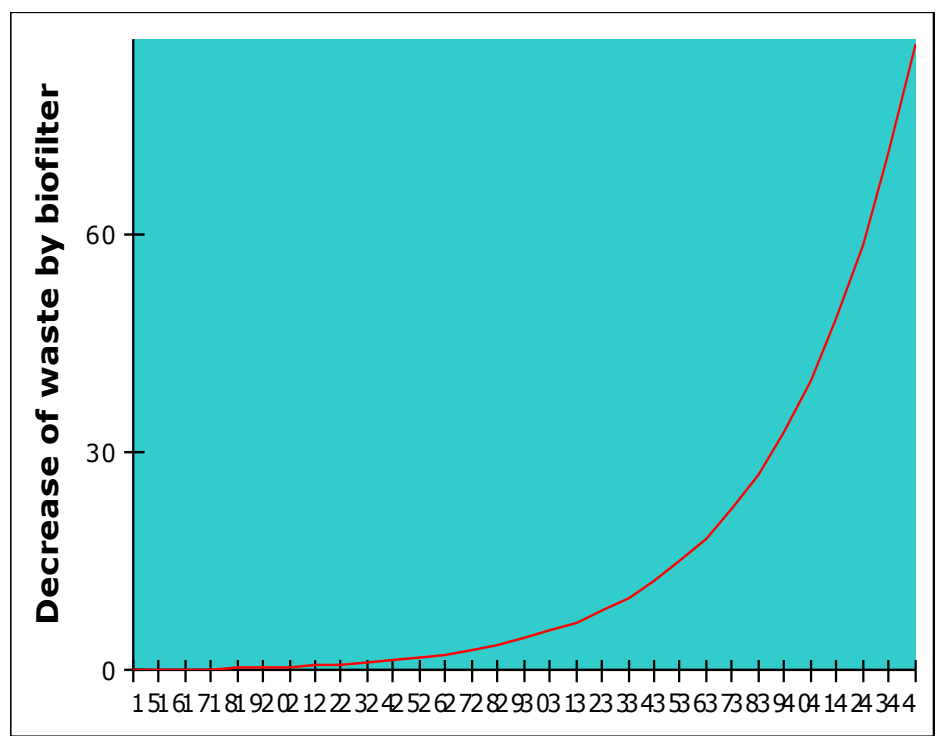

Figure 7 - Simulation graph of waste reduction by Biofilter (Kg/Year)

Simulation of the role of biofilter in reducing waste shows that in year 2024 seaweed type gracilaria $\mathrm{sp}$ exponentially decreasing waste. The rate of waste reduction by seaweed in the year amounted to 1.07 tons per year. Based on the simulation, in 2045 the waste reduction reached 86.17 tons. The decrease of cultivation waste in the presence of seaweed biofilter is correlated with increasing seaweed biomass as time increases. 


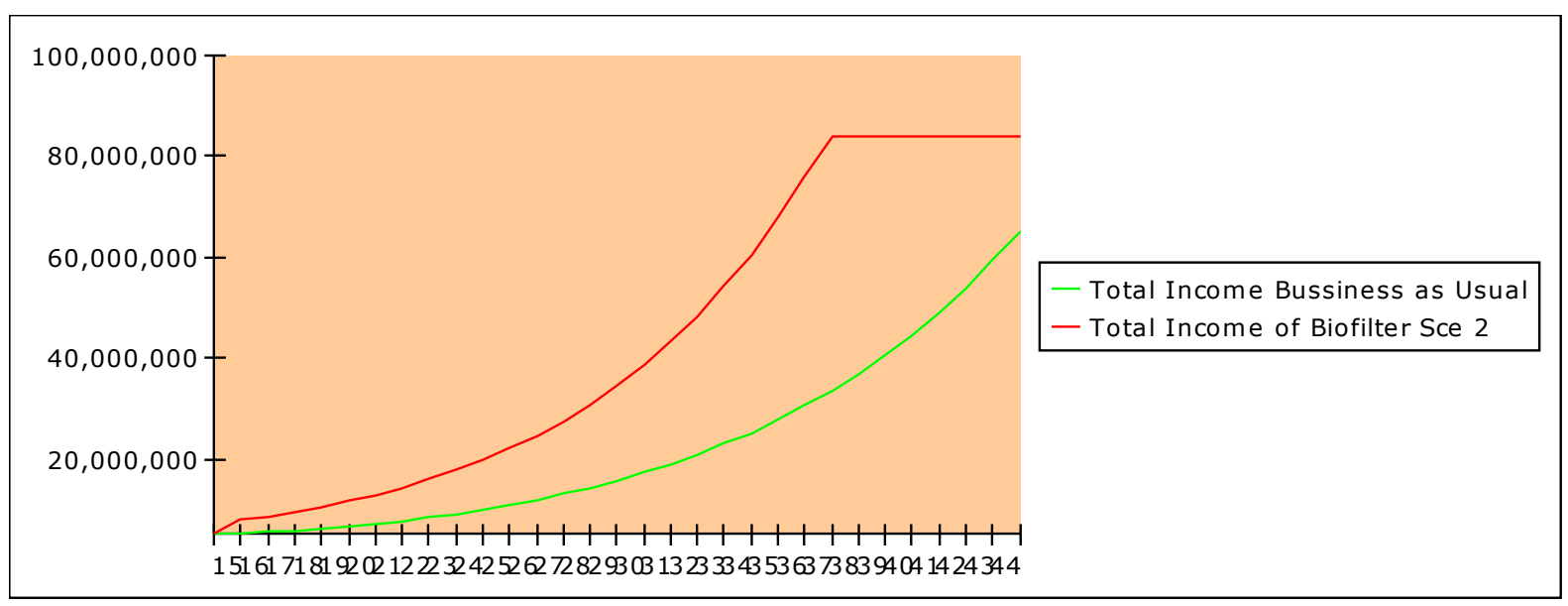

Figure 8 - Graph of simulated total income of cultivation

The results of business as usual income simulation in the first year amounted to $\mathrm{Rp}$ 50.000 .000 , -. The income of the community in the first year with the scenario of increasing the biofilter coefficient from 1 to 1.2 has increased the income to Rp 70,925,190. The income level of the cultivators using biofilter reaches its peak in 2038 with income reaching $\mathrm{Rp}$ $830,697,159$.- After 2038 the amount of income tends to remain, as the saturation level of seaweed filters the cultivation waste.

\section{DISCUSSION OF RESULTS}

In most open shrimp cultivation systems $90 \%$ of $\mathrm{N}$ and $\mathrm{P}$ inputs are in the form of feed, and most of them are lost into the system and less than one-sixth are assimilated in shrimp biomass. Shrimp can only assimilate about $23-31 \% \mathrm{~N}$ and $10-13 \% \mathrm{P}$ at total input. The main source of nutrient input for shrimp is feed, which contains about $76-92 \% \mathrm{~N}$ and $70-91 \% \mathrm{P}$ of total input. The main nutrients are submerged in the sediments of $14-53 \% \mathrm{~N}$ and $39-67 \% \mathrm{P}$ of total inputs. The water that flows at harvest contains $14-28 \% \mathrm{~N}$ and $12-29 \% \mathrm{P}$ of the total input. Nitrogen content is a limiting factor for seaweed cultivation because it plays a role in regulating growth also in the regulation of metabolism and reproduction. Assimilation $\mathrm{N}$ requires an inorganic form of $\mathrm{N}$ in the seawater environment to become an organic form, such as amino acids and other components. This is because $\mathrm{N}$ is indispensable for the biosynthesis of amino acids and proteins. The nitrogen content may vary or not on the Eucheuma thallus. while $\mathrm{NH} 4+$ in aquaculture medium is known to decrease during the study. In principle, changes in the water column have been utilized by seaweed, and most of the $\mathrm{N}$-ammonia present in the pond has been used to a low level $<10 \mu \mathrm{M}$. In addition, seaweed can also significantly alter the amount of phosphate present in the water. Seaweed can utilize nitrite and nitrate when $\mathrm{N}$-ammonia is below 1 to $2 \mathrm{mg} / \mathrm{I}$ (Risjani, 2000).

Orthophosphate (PO4) is a phosphate fraction that can be directly absorbed by phytoplankton in photosynthesis. In general, phosphate is found in natural waters in small concentrations. Phosphate concentration of $1 \mathrm{mg} / \mathrm{I}$ is optimal enough for the growth of phytoplankton. Boyd (1988), states that the presence of phosphorus in natural waters is usually relatively small, levels less than nitrogen, because fewer sources of phosphorus than nitrogen sources in the waters. Phosphate is one of the macronutrient for algae in the waters. In aquatic ecosystems phosphorous shaped into organic and inorganic compound. Phosphorus in inorganic compounds is orthophosphate (PO4), metaphosphate and polyphosphate, whereas organic phosphate is present in the body of an organism or organic compound. Phosphate compounds have break-off cycles due to their reactive nature that is easily bound by sediment but is difficult to dissolve back into the water. The accuracy of the concentration of orthophosphate in water will stabilize the growth of phytoplankton.

Seaweed or algae as other chlorophyll plants require nutrients as raw materials for the process of photosynthesis. To support the growth required the availability of nutrients in the 
water. Entry of materials or nutrients into the body tissue of seaweed is by the process of diffusion that occurs on all parts of the surface of the body of seaweed. When more diffusion, will accelerate the metabolism process that will increase the rate of growth. The diffusion process is influenced by environmental factors primarily by the presence of water movement (Boyd, 1988).

Model simulation results show the level of seaweed's ability to absorb cultivation waste. Over the years, cultivation wastes will be absorbed larger by the behavior of the exponential growth model. Absorption rate of waste by seaweed Gracilaria sp. based on the simulation will decrease the ability as time increases. Gracilaria sp. Seaweed capability in improving water quality, based on model will increase cultivation productivity and farmer's income. Mulatsih and Nurjanah (2015) stated that the existence of seaweed cultivation in brackish water can improve the quality of brackish environment, especially the organic matter of nitrate and phosphate.

\section{CONCLUSION}

The existence of seaweed with density $18 \mathrm{gram} / \mathrm{m}^{2}$ give a significant influence to the reduction of Nitrogen and Phospor level as nutrient elements in aquaculture media so that affect the increasing productivity of shrimp farming and increase the income of farmer community. Further study needs to be done related to the role of seaweed Gracillaria sp in absorbing metal elements that affect the productivity of tiger shrimp in the cultivation of polyculture.

\section{ACKNOWLEDGMENTS}

This scientific article is part of the Competitive Grant Research Report of the Directorate General of Higher Education (Kemristekdikti) of Fiscal Year 2015. For that reason, thanks are conveyed to the Director of Directorate of Higher Education for the funding that has been given for the smoothness of this research.

\section{REFERENCES}

1. Boyd, C.E. 1988. Water Quality in Warmwater Fish Brackhishs. Fourth Printing. Auburn University Agricultural Experiment Station, Alabama, USA.

2. Muhamadi, E. Aminullah and B. Soesilo. 2001. Dynamic Systems Analysis of Environment, Social, Economics and Management. Center for Policy Studies and System Dynamics - Publisher UMJ Press. Jakarta. $415 \mathrm{p}$.

3. Mulatsih and Nurjanah. 2015. Model of Optimization of Environmental Quality Management through the Role of Seaweed Biofilter (Gracilaria sp.) For Sustainable Farm Development. OSEATEK Juni 2015 Vol. 9 (01).

4. Morecroft JDW. 2007. Strategic Modeling and Business Dynamics: a FeedbackSystem Approach. England: John Wiley \& Sons Ltd.

5. Risjani, Y. 2000. N Assimilation in the apical tissue of seaweed Eucheuma alvarezii. International Symposium on Marine Biothechnology. Center for Coastal and Marine Resources Studies, Faculty of Fisheries and Marine Science IPB. Bogor.

6. Siregar, S. 2013. Parametric Statistics for Quantitative Research. PT Bumi Aksara. Jakarta. 538 p.

7. Sutaman. 2017. Sustainability Strategy Utilization of Fishery and Marine Tourism Resources on Coastal And Small Islands Areas Biak Numfor Regency. [Disertasi]. IPB. Bogor. 